\title{
Paenibacillus algorifonticola sp. nov., isolated from a cold spring
}

\author{
Qi-Yong Tang, ${ }^{1}$ † Na Yang, ${ }^{2,3}$ † Jian Wang, ${ }^{2}$ Yu-Oing Xie, ${ }^{1}$ Biao Ren, ${ }^{2,3}$ \\ Yu-Guang Zhou, ${ }^{2}$ Mei-Ying Gu, ${ }^{1}$ Jun Mao, ${ }^{1}$ Wen-Jun Li, ${ }^{2,4}$ Yu-Hu Shi ${ }^{1}$ \\ and Li-Xin Zhang ${ }^{2,5,6}$
}

Correspondence

Li-Xin Zhang

zhanglixin@im.ac.cn

\begin{abstract}
${ }^{1}$ Institute of Microbiology, Xinjiang Academy of Agricultural Sciences, Urumqi 830091, Xinjiang Uyghur Autonomous Region, PR China

${ }^{2}$ Chinese Academy of Sciences Key Laboratory of Pathogenic Microbiology and Immunology, Institute of Microbiology, Chinese Academy of Sciences, Beijing 100190, PR China

${ }^{3}$ Graduate University, Chinese Academy of Science, Beijing 100049, PR China

${ }^{4}$ The Key Laboratory for Microbial Resources of the Ministry of Education, PR China, and Laboratory for Conservation and Utilization of Bio-resources, Yunnan Institute of Microbiology, Yunnan University, Kunming, Yunnan, 650091, PR China

${ }^{5}$ Guangdong Key Laboratory of Marine Materia Medica, South China Sea Institute of Oceanology, Chinese Academy of Sciences, Guangzhou, 510301, PR China
\end{abstract}

${ }^{6}$ SynerZ Pharmaceuticals Inc., Lexington, MA 02421, USA

A Gram-stain-positive, endospore-forming, rod-shaped bacterium, designated XJ259 ${ }^{\top}$, was isolated from a cold spring sample from Xinjiang Uyghur Autonomous Region, China. The isolate grew optimally at $20-30{ }^{\circ} \mathrm{C}$ and $\mathrm{pH} 7.3-7.8$. Comparative analysis of the 16S rRNA gene sequence showed that isolate $\mathrm{XJ} 259^{\top}$ belonged phylogenetically to the genus Paenibacillus, and was most closely related to Paenibacillus xinjiangensis $\mathrm{B}^{2} 38^{\top}$ (with $96.6 \%$ sequence similarity), Paenibacillus glycanilyticus DS $-1^{\top}$ (96.3\%) and Paenibacillus castaneae Ch-32 ${ }^{\top}$ (96.1\%), sharing less than $96.0 \%$ sequence similarity with all other members of the genus Paenibacillus. Chemotaxonomic analysis revealing menaquinone-7 (MK-7) as the major isoprenoid quinone, diphosphatidylglycerol, phosphatidylethanolamine and two unknown phosphoglycolipids as the major cellular polar lipids, a DNA G+C content of $47.0 \mathrm{~mol} \%$, and anteiso- $\mathrm{C}_{15: 0}$ and $\mathrm{C}_{16: 0}$ as the major fatty acids supported affiliation of the new isolate to the genus Paenibacillus. Based on these data, isolate $\mathrm{XJ} 259^{\top}$ is considered to represent a novel species of the genus Paenibacillus, for which the name Paenibacillus algorifonticola sp. nov. is proposed. The type strain is XJ259 ${ }^{\top}$ $\left(=\right.$ CGMCC $1.10223^{\top}=$ JCM 16598 $\left.{ }^{\top}\right)$.
The genus Paenibacillus was delineated from members of group 3 Bacillus based on 16S rRNA gene sequence analysis by Ash et al. (1993), and the proposal was validly published in 1994. Following the establishment of the genus, more species were recognized and some characteristics in the original genus description were not found in several species. Therefore, the description of the genus Paenibacillus was emended by Shida et al. (1997). Furthermore, Paenibacillus polymyxa (Ash et al., 1993, 1994) was considered as the type species of the genus by the Judicial

†These authors contributed equally to this work.

The GenBank/EMBL/DDBJ accession number for the 16S rRNA gene sequence of strain XJ259 ${ }^{\top}$ is GQ383922.

Three supplementary figures are available with the online version of this paper.
Commission in 2005 (Judicial Commission of the International Committee for Systematics of Prokaryotes, 2005). At the time of writing, 117 species with validly published names were recognized as members of the genus Paenibacillus (http://www.bacterio.cict.fr/p/paeniba cillus.html). Species belonging to this genus were mostly aerobic or facultatively anaerobic, rod-shaped, endosporeforming bacteria, possessing anteiso- $\mathrm{C}_{15: 0}$ as the major cellular fatty acid and having genomic DNA G + C contents in the range 39-54 mol\% (Shida et al., 1997; Montes et al., 2004; Takeda et al., 2005). They had been isolated from various habitats such as warm springs (Saha et al., 2005; Chou et al., 2007), food (Berge et al., 2002), cow faeces (Velázquez et al., 2004), Antarctic sediment (Montes et al., 2004), phyllosphere (Rivas et al., 2005, 2006; Valverde et al., 2008), alkaline soil (Yoon et al., 2005), Pu'er tea 
(Kim et al., 2009), rhizosphere (Daane et al., 2002; Kuisiene et al., 2008), insects (Park et al., 2009) and clinical specimens such as human blood (Ko et al., 2008; Roux \& Raoult, 2004) or human cerebrospinal fluid (Roux et al., 2008). In this paper, the taxonomic position of a cold spring isolate, $\mathrm{XJ} 259^{\mathrm{T}}$, which was found to be phylogenetically related to members of the genus Paenibacillus, was determined by using a polyphasic taxonomic approach and by comparisons based on preliminary $16 \mathrm{~S}$ rRNA gene sequence analysis with reference strains belonging to the most closely related species of the genus Paenibacillus, Paenibacillus xinjiangensis, Paenibacillus castaneae and Paenibacillus glycanilyticus.

Strain $\mathrm{XJ} 259^{\mathrm{T}}$ was isolated from a cold spring water sample from the city Urumchi of Xinjiang Uyghur Autonomous Region by dilution-plating on TYEG agar and incubating at $10{ }^{\circ} \mathrm{C}$ for 3 days. TYEG agar contained $10 \mathrm{~g}$ tryptone, $5 \mathrm{~g}$ yeast extract, $5 \mathrm{~g}$ glucose, $3 \mathrm{~g} \mathrm{~K}_{2} \mathrm{HPO}_{4}$ and $20 \mathrm{~g}$ agar in $1000 \mathrm{ml}$ distilled water, $\mathrm{pH}$ 7.0. The isolate was routinely maintained on TYEG agar slants at $4{ }^{\circ} \mathrm{C}$ and preserved as suspensions of cells in glycerol $(20 \%, \mathrm{v} / \mathrm{v})$ at $-70{ }^{\circ} \mathrm{C}$, as were the three closely related type strains, $P$. xinjiangensis B538 ${ }^{\mathrm{T}}\left(=\mathrm{DSM} 16970^{\mathrm{T}}\right)$, P. castaneae Ch- $32^{\mathrm{T}}(=\mathrm{DSM}$ $19417^{\mathrm{T}}$ ) and P. glycanilyticus DS- $\mathrm{1}^{\mathrm{T}}$ (=NBRC $16618^{\mathrm{T}}$ ), which were supplied by the German Resource Centre for Biological Material (DSMZ) and the NITE Biological Resource Centre (NBRC).

The 16S rRNA gene sequence of strain XJ259 ${ }^{\mathrm{T}}$ (1519 nt) was determined and analysed as described by Lane (1991), with some modifications. For initial taxonomic classification of the sequence, a combination of BLAST search (Altschul et al., 1997, http://www.ncbi.nlm.nih.gov/blast) and the IDENTIFY program of the online server of EzTaxon (http://www.eztaxon.org/) was used (Chun et al., 2007). For phylogenetic analysis, 16S rRNA gene sequences of type strains of all recognized species of the genus Paenibacillus downloaded from DDBJ/EMBL/GenBank were used; sequences shorter than $1300 \mathrm{nt}$ or containing ambiguous nucleotides were excluded. A similarity matrix of all $16 \mathrm{~S}$ rRNA gene sequences was generated after multiple alignment of the data by using CLUSTAL $\mathrm{x}$ (Thompson et al., 1997), and, accordingly, 19 of the most closely related sequences were chosen to make a relatively small tree. The $16 \mathrm{~S}$ rRNA gene sequences of Oxalophagus oxalicus DSM

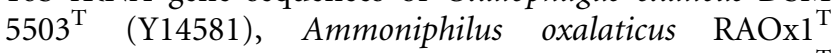
(Y14578) and Aneurinibacillus aneurinilyticus DSM $5562^{\mathrm{T}}$ (X94194) were selected as an outgroup. Three tree reconstruction methods were employed in this study. The neighbour-joining tree (Saitou \& Nei, 1987) was calculated by using distances corrected according to the Kimura twoparameter model (Kimura, 1980, 1983) with the software package MEGA version 4.0 (Kumar et al., 2008; Tamura et al., 2007). For reconstruction of the maximumparsimony tree, the software package PHYLIP version 3.6 (Felsenstein, 2002) was used. For reconstruction of the maximum-likelihood tree, the online version of PhyML (Guindon et al., 2005) was used. The topology of the trees was evaluated by performing a bootstrap analysis (Felsenstein, 1985) of 1000 resamplings. The DNA G +C content of strain $\mathrm{XJ} 259^{\mathrm{T}}$ was determined by using the thermal denaturation method (Mandel \& Marmur, 1968), with Escherichia coli K-12 (CGMCC 1.748) as the reference, employing a PerkinElmer LAMBDA 25 UV/Vis spectrophotometer with a thermal controller.

A range of chemotaxonomic studies was carried out to confirm whether the chemical profile of strain $\mathrm{XJ} 259^{\mathrm{T}}$ supported its assignment to the genus Paenibacillus. Cellular biomass for chemical studies was obtained by cultivation in shaken flasks (150 r.p.m.) with TYEG broth (pH 7.5) at $25^{\circ} \mathrm{C}$ for 3 days unless indicated otherwise. Analysis of whole-cell fatty acids of isolate $\mathrm{XJ} 259^{\mathrm{T}}$ and the three reference strains was

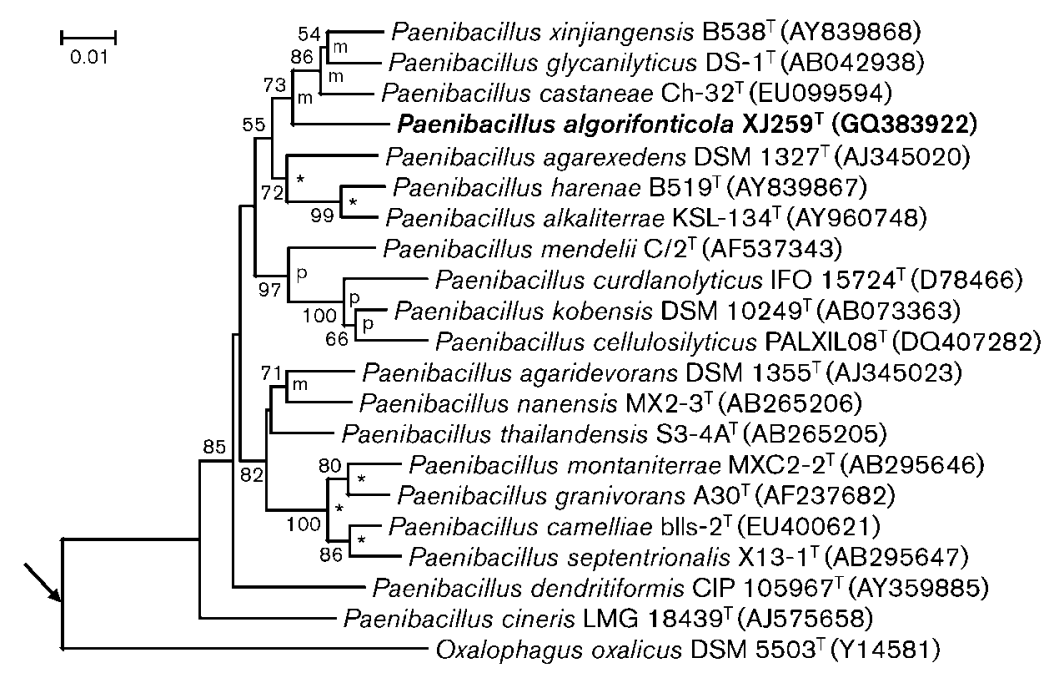

Fig. 1. Neighbour-joining tree showing phylogenetic relationships between strain $\mathrm{XJ} 259^{\top}$ and the most closely related species belonging to the genus Paenibacillus based on $16 \mathrm{~S}$ rRNA gene sequences. Asterisks at nodes indicate branches recovered with all three methods; $m$ and $p$ indicate branches which are also recovered by using the maximumlikelihood (Felsenstein, 1981) and maximumparsimony (Kluge \& Farris, 1969) treeing algorithms, respectively. Arrow indicates the estimated position of the three root organisms, including O. oxalicus DSM 5503 ${ }^{\top}$ (Y14581), Ammoniphilus oxalaticus $\mathrm{RAOx} 1^{\top}$ (Y14578) and Aneurinibacillus aneurinilyticus DSM $5562^{\top}$ (X94194). Bootstrap values are shown as percentages of 1000 replicates; only values $>50 \%$ are shown. Bar, 0.01 substitutions per nucleotide position. 
performed according to the Microbial Identification System (MIDI; Microbial ID) after cultivation in TSB (tryptic soy broth; BD Bacto) for 2 days at $25{ }^{\circ} \mathrm{C}$. Polar lipids were extracted and examined by one- and two-dimensional TLC on Merck silica gel 60 F254 aluminium-backed thin-layer plates according to the procedures described by Kates (1986) and Collins et al. (1980). Freeze-dried cells were collected and analysis of the peptidoglycan was carried out by using the method described by Schleifer \& Kandler (1972), with the modification that TLC was performed on a microcrystalline cellulose plate. Isoprenoid quinones were determined as described by Komagata \& Suzuki (1987).

Gram staining of strain $\mathrm{XJ} 259^{\mathrm{T}}$ was performed according to the modified method of Hucker (1921). Cell morphology was observed by using a light microscope (Olympus CX41) and a transmission electron microscope (Hitachi H600) as described by Jeon et al. (2005). Motility was observed at 12 and $36 \mathrm{~h}$ with the light microscope. Anaerobic growth was tested as described by Valverde et al. (2008). Growth was tested at different temperatures $\left(4-55{ }^{\circ} \mathrm{C}\right)$ and at different $\mathrm{pH}(4.0-11.0)$ at $25{ }^{\circ} \mathrm{C}$ in TYEG broth. Media with different $\mathrm{pH}$ were prepared by using appropriate biological buffers; $\mathrm{Na}_{2} \mathrm{HPO}_{4} / \mathrm{NaH}_{2} \mathrm{PO}_{4}, \quad \mathrm{Na}_{2} \mathrm{CO}_{3} / \mathrm{NaHCO}_{3}$ and $\mathrm{Na}_{2} \mathrm{HPO}_{4} /$ $\mathrm{NaOH}$ were used for $\mathrm{pH}$ below 8.0, $\mathrm{pH} 8.0-10.0$ and $\mathrm{pH} 11.0$, respectively (Gomori, 1955). Requirements for and tolerance of $\mathrm{NaCl}$ were determined in TYEG medium supplemented with $\mathrm{NaCl}(0-10 \%, w / v)$. Oxidase and catalase activities, hydrolysis of casein, gelatin and Tweens 20, 40 and 80, Methyl Red/Voges-Proskauer reaction, indole test, $\mathrm{H}_{2} \mathrm{~S}$ production and nitrate reduction were determined as reported by Barrow \& Feltham (1993). Hydrolysis of starch was tested by using starch agar with $95 \%$ ethanol and Gram's iodine (Claus \& Berkeley, 1986). Metabolism of citrate was tested by using Simmons' citrate medium (Smibert \& Krieg, 1981). Acid production from L-rhamnose, D-mannose, D-ribose, D-galactose, D-arabinose, D-fructose, raffinose, D-xylose, L-sorbose, maltose, sucrose, lactose, D-glucose, inositol, trehalose, mannitol and glycerol was evaluated in basal medium (beef extract, $0.3 \%$; tryptose, $1 \%$; $\mathrm{NaCl}, 0.5 \%$ ) containing $0.003 \%(\mathrm{w} / \mathrm{v})$ bromophenol blue and $1 \%$ each carbohydrate according to the modified method of Leifson (1963) after 3 days of cultivation at $25{ }^{\circ} \mathrm{C}$. Utilization of 96 substrates as sole carbon source was tested using Biolog GP2 plates.

Comparisons with 16S rRNA gene sequences from the GenBank/EMBL/DDBJ database revealed that the novel strain (1519 nt) had the highest similarity to P. xinjiangensis ${\mathrm{B} 538^{\mathrm{T}}}^{(96.6 \%)}$ (Lim et al., 2006), followed by P. glycanilyticus DS- $1^{\mathrm{T}}(96.3 \%)$ (Dasman et al., 2002) and P. castaneae Ch-32 ${ }^{\mathrm{T}}$ (96.1\%) (Valverde et al., 2008). 16S rRNA gene sequence similarities of strain $\mathrm{XJ} 259^{\mathrm{T}}$ with the other recognized species of the genus Paenibacillus were less than $96.0 \%$. Neighbour-joining phylogenetic analysis based on 16S rRNA gene sequence analysis revealed that strain $\mathrm{XJ} 259^{\mathrm{T}}$ formed a robust cluster with the three most closely related species of the genus Paenibacillus (Fig. 1 and Supplementary Fig. S1, available in IJSEM Online); the bootstrap value obtained was above $70 \%$ in the small tree (Fig. 1). Phylogenetic trees built by using the maximumparsimony and maximum-likelihood algorithms were similar to the neighbour-joining tree and also supported inclusion of isolate $\mathrm{XJ} 259^{\mathrm{T}}$ in the genus Paenibacillus.

The DNA G + C content of isolate $\mathrm{XJ} 259^{\mathrm{T}}$ was $47.0 \mathrm{~mol} \%$. Strain $\mathrm{XJ}_{259^{\mathrm{T}}}$ contained anteiso- $\mathrm{C}_{15: 0}(63.2 \%), \mathrm{C}_{16: 0}$ $(13.7 \%)$, iso- $\mathrm{C}_{16: 0}(6.0 \%)$, iso- $\mathrm{C}_{15: 0}(4.7 \%)$ and iso$\mathrm{C}_{14: 0}(4.6 \%)$ as the major cellular fatty acids; other components were less than $4.0 \%$. This profile was consistent with those of closely related neighbours tested in parallel (Table 1), but, unlike the reference strains, the proportion of saturated straight-chain fatty acid $\mathrm{C}_{16: 0}$ was relatively high

Table 1. Cellular fatty acid profiles of strain $\mathrm{XJ} 259^{\top}$ and related type strains

Strains: 1, P. algorifonticola sp. nov. XJ259 ${ }^{\mathrm{T}} ; 2$, P. xinjiangensis $\mathrm{B} 538^{\mathrm{T}}$ $\left(=\mathrm{DSM} 16970^{\mathrm{T}}\right) ; 3$, P. glycanilyticus DS- ${ }^{\mathrm{T}}\left(=\mathrm{NBRC} 16618^{\mathrm{T}}\right) ; 4, P$. castaneae Ch-32 ${ }^{\mathrm{T}}\left(=\mathrm{DSM} 19417^{\mathrm{T}}\right)$. Values shown are percentages of total fatty acids. -, Not detected. All strains were tested concurrently.

\begin{tabular}{|c|c|c|c|c|}
\hline Fatty acid & 1 & 2 & 3 & 4 \\
\hline \multicolumn{5}{|c|}{ Saturated straight-chain } \\
\hline $\mathrm{C}_{10: 0}$ & - & 1.13 & - & 1.70 \\
\hline $\mathrm{C}_{12: 0}$ & 0.14 & 1.30 & 0.24 & 0.58 \\
\hline $\mathrm{C}_{14: 0}$ & 3.50 & 3.36 & 1.39 & 1.39 \\
\hline $\mathrm{C}_{15: 0}$ & - & - & - & - \\
\hline$C_{16: 0}$ & 13.69 & 9.60 & 7.77 & 5.41 \\
\hline $\mathrm{C}_{17: 0}$ & - & - & - & - \\
\hline $\mathrm{C}_{18: 0}$ & - & - & - & 0.08 \\
\hline \multicolumn{5}{|c|}{ Saturated iso-branched } \\
\hline iso- $\mathrm{C}_{11: 0}$ & 0.10 & - & - & - \\
\hline iso- $\mathrm{C}_{13: 0}$ & - & 0.15 & - & 0.47 \\
\hline iso- $\mathrm{C}_{14: 0}$ & 4.58 & 3.17 & 3.54 & 1.64 \\
\hline iso- $\mathrm{C}_{15: 0}$ & 4.71 & 7.17 & 4.52 & 8.76 \\
\hline iso- $\mathrm{C}_{16: 0}$ & 6.01 & 4.70 & 20.38 & 3.29 \\
\hline iso- $\mathrm{C}_{17: 0}$ & 1.38 & 2.48 & 1.06 & 1.46 \\
\hline iso- $\mathrm{C}_{19: 0}$ & - & - & 0.07 & - \\
\hline \multicolumn{5}{|c|}{ Saturated anteiso-branched } \\
\hline anteiso- $\mathrm{C}_{11: 0}$ & 0.06 & 0.98 & 0.82 & 0.43 \\
\hline anteiso- $\mathrm{C}_{13: 0}$ & 0.09 & 0.25 & - & 0.80 \\
\hline anteiso- $\mathrm{C}_{15: 0}$ & 63.21 & 60.24 & 56.56 & 71.27 \\
\hline anteiso- $\mathrm{C}_{17: 0}$ & 2.25 & 2.86 & 3.12 & 2.57 \\
\hline \multicolumn{5}{|l|}{ Unsaturated } \\
\hline 11-Methyl $\mathrm{C}_{18: 1} \omega 7 c$ & 0.08 & - & - & - \\
\hline $\mathrm{C}_{16: 1} \omega 7 c$ alcohol & - & 0.26 & - & - \\
\hline $\mathrm{C}_{16: 1} \omega 11 c$ & - & 2.05 & - & - \\
\hline $\mathrm{C}_{20: 1} \omega 7 c$ & - & - & 0.06 & - \\
\hline \multicolumn{5}{|l|}{ Hydroxy } \\
\hline iso- $\mathrm{C}_{11: 0} 3-\mathrm{OH}$ & 0.06 & 0.20 & - & 0.08 \\
\hline iso- $\mathrm{C}_{13: 0} 3-\mathrm{OH}$ & - & - & 0.35 & - \\
\hline iso- $\mathrm{C}_{14: 0} 3-\mathrm{OH}$ & - & 0.10 & - & - \\
\hline $\mathrm{C}_{15: 0} 2-\mathrm{OH}$ & - & - & - & 0.06 \\
\hline \multicolumn{5}{|l|}{ Summed feature ${ }^{\star}$} \\
\hline 3 & 0.07 & - & 0.12 & - \\
\hline
\end{tabular}

${ }^{\star}$ Summed feature 3 consists of $\mathrm{C}_{16: 1} \omega 7 c$ and/or $\mathrm{C}_{16: 1} \omega 6 c$. 
in strain $\mathrm{XJ} 259^{\mathrm{T}}$. Isolate $\mathrm{XJ} 259^{\mathrm{T}}$ contained MK-7 as the major isoprenoid quinone, in accordance with other representatives of the genus Paenibacillus. Diphosphatidylglycerol, phosphatidylethanolamine and two unknown phosphoglycolipids were detected as the major polar lipids. The diagnostic cell-wall diamino acid in the peptidoglycan layer of isolate $\mathrm{XJ} 259^{\mathrm{T}}$ was meso-diaminopimelic acid, and the major whole-cell sugars were rhamnose and ribose.

Isolate XJ259 ${ }^{\mathrm{T}}$ grew well on TSA (tryptic soy agar; BD Bacto), nutrient agar (NA; BD Bacto), LB agar and TYEG agar, and formed smooth, circular to fried-egg-formed and cream coloured colonies on all agars in this study after 3 days of incubation at $25{ }^{\circ} \mathrm{C}$. The strain grew at $10-37{ }^{\circ} \mathrm{C}$ (optimum, 20-30 ${ }^{\circ} \mathrm{C}$ ), $\mathrm{pH} 7.0-8.0$ (optimum, $\mathrm{pH} 7.3-7.8$ ) and $0-3 \%$ $(\mathrm{w} / \mathrm{v}) \mathrm{NaCl}$ (optimum, $0-1 \%)$. Isolate $\mathrm{XJ} 259^{\mathrm{T}}$ was Gramstain-positive, oxidase-negative, catalase-positive, and positive for hydrolysis of Tweens 20 and 40. Freshly isolated cells were rod-shaped $(0.7-1.0 \mu \mathrm{m}$ wide and $2.0-3.2 \mu \mathrm{m}$ long) and motile with peritrichous flagella (Supplementary Fig. S2). Ellipsoidal endospores were produced after 4 days of growth on 10-fold diluted TYEG medium supplemented with $5 \mathrm{mg} \mathrm{MnSO}_{4} \mathrm{I}^{-1}$ (Supplementary Fig. S3). Biolog GP2 plate results revealed that isolate $\mathrm{XJ} 259^{\mathrm{T}}$ could use $\alpha$-cyclodextrin, cyclodextrin, dextrin, arbutin, cellobiose, D-fructose, gentiobiose, $\alpha$-D-glucose, maltose, maltotriose, D-mannose, melibiose, D-psicose and salicin as sole carbon source. Other phenotypic characters of strain $\mathrm{XJ} 259^{\mathrm{T}}$ and comparisons with strains of related species are detailed in Table 2. All the phenotypic data of strain $\mathrm{XJ} 259^{\mathrm{T}}$ were in accordance with its assignment to the genus Paenibacillus, and obvious differences were observed from the related strains (Table 2). Colonies of strain XJ259 ${ }^{\mathrm{T}}$ grew firmly on all agars tested and were very hard to scrape off, whereas colonies of the other strains grew softly on agar plates. Anaerobic growth was observed for strain XJ259 ${ }^{\mathrm{T}}$ but not for the other strains. Strain $\mathrm{XJ} 259^{\mathrm{T}}$ was found to grow within a comparatively narrow $\mathrm{pH}$ range (7.0-8.0), whereas the other strains could grow at relatively wide ranging $\mathrm{pH}$ and appeared moderately acid-tolerant. Besides, the acid-production pattern of strain $\mathrm{XJ} 259^{\mathrm{T}}$ from a range of carbon sources was different from those of other species of the genus Paenibacillus, e.g. acid was not produced from trehalose by strain $\mathrm{XJ} 259^{\mathrm{T}}$, but was produced by the other strains tested.

All of the characteristics determined for strain $\mathrm{XJ} 259^{\mathrm{T}}$ were in accordance with those for the genus Paenibacillus. However, the phylogenetic distances from recognized species of the genus Paenibacillus and the combination of unique phenotypic characteristics indicated that strain $\mathrm{XJ} 259^{\mathrm{T}}$ is not affiliated to any of these recognized species. Therefore, it is concluded that strain XJ259 $9^{\mathrm{T}}$ represents a novel species of the genus Paenibacillus, for which the name Paenibacillus algorifonticola sp. nov. is proposed.

Table 2. Physiological properties of strain $\mathrm{XJ} 259^{\top}$ and type strains of related species of the genus Paenibacillus

Strains: 1, P. algorifonticola sp. nov. XJ259 $; 2$, P. xinjiangensis $\mathrm{B} 538^{\mathrm{T}}\left(=\mathrm{DSM} 16970^{\mathrm{T}}\right) ; 3$, P. glycanilyticus $\mathrm{DS}-1^{\mathrm{T}}\left(=\mathrm{NBRC} 16618^{\mathrm{T}}\right) ; 4$, P. castaneae Ch- $32^{\mathrm{T}}\left(=\right.$ DSM $\left.19417^{\mathrm{T}}\right)$. +, Positive reaction; -, negative reaction. All strains were positive for catalase and hydrolysis of Tweens 20 and 40 . All strains were negative for nitrate reduction, $\mathrm{H}_{2} \mathrm{~S}$ production, and hydrolysis of citrate, casein and Tween 80 . Acids were produced by all strains from the following carbon sources: D-glucose, D-mannose, D-galactose, D-arabinose, raffinose, D-xylose, maltose, sucrose and lactose. Acids were not produced by all strains from the following carbon sources: L-sorbose and inositol.

\begin{tabular}{|c|c|c|c|c|}
\hline Characteristic & 1 & 2 & 3 & 4 \\
\hline Colony colour & Cream & White-cream & Pinkish yellow & Yellow \\
\hline Endospore position & Terminal & Terminal & Subterminal & Subterminal \\
\hline Anaerobic growth & + & - & - & - \\
\hline Oxidase & - & - & - & + \\
\hline \multicolumn{5}{|l|}{ Hydrolysis of: } \\
\hline Starch & + & + & + & - \\
\hline Gelatin & - & - & - & + \\
\hline \multicolumn{5}{|l|}{ Acid production from: } \\
\hline D-Ribose & + & + & + & - \\
\hline D-Fructose & + & + & + & - \\
\hline Trehalose & - & + & + & + \\
\hline Mannitol & + & - & + & + \\
\hline Glycerol & - & + & + & - \\
\hline Tolerance to $\mathrm{NaCl}(\%, \mathrm{w} / \mathrm{v})$ & $0-3$ & $0-3$ & $0-5$ & $0-2.5$ \\
\hline Temperature range $\left({ }^{\circ} \mathrm{C}\right)$ & $10-37$ & $10-40$ & $10-40$ & $4-40$ \\
\hline Optimum growth temperature $\left({ }^{\circ} \mathrm{C}\right)$ & $20-30$ & $30-35$ & $28-37$ & $15-30$ \\
\hline $\mathrm{pH}$ range & $7.0-8.0$ & $6.5-9.5$ & $5.5-8.0$ & $5.5-8.5$ \\
\hline DNA G $+\mathrm{C}$ content $(\mathrm{mol} \%)$ & 47.0 & 47.0 & 50.5 & 46.0 \\
\hline
\end{tabular}




\section{Description of Paenibacillus algorifonticola sp. nov.}

Paenibacillus algorifonticola [al.go.ri.fon.ti'co.la. L. n. algor the cold; L. n. fons fontis a spring; L. suff. -cola (from L. masc. or fem. n. incola) an inhabitant of a place, a resident; N.L. n. algorifonticola an inhabitant of a cold spring].

Cells are rod-shaped, approximately $0.7-1.0 \mu \mathrm{m}$ wide and 2.0-3.2 $\mu \mathrm{m}$ long, facultatively anaerobic, Gram-stain-positive, and motile with peritrichous flagella. Ellipsoidal spores are produced within a swollen sporangium and situated terminally. Catalase-positive and oxidase-negative. Colonies are smooth, circular to fried-egg-formed and cream coloured on TYEG agar. Growth occurs at $10-37{ }^{\circ} \mathrm{C}$ (optimum, 20$30{ }^{\circ} \mathrm{C}$ ), with $0-3 \%(\mathrm{w} / \mathrm{v}) \mathrm{NaCl}$ (optimum, $0-1 \%$ ) and at pH 7.0-8.0 (optimum, pH 7.3-7.8). Hydrolysis of starch and Tweens 20 and 40 is positive. Hydrolysis of Tween 80, citrate, casein and gelatin is negative. Nitrate is not reduced to nitrite. Methyl Red/Voges-Proskauer reaction, indole test and $\mathrm{H}_{2} \mathrm{~S}$ production are negative. Acids are produced from D-mannose, D-ribose, D-galactose, D-arabinose, D-fructose, raffinose, D-xylose, maltose, sucrose, lactose, D-glucose and mannitol, but not from L-sorbose, inositol, trehalose or glycerol. Cells can use $\alpha$-cyclodextrin, cyclodextrin, dextrin, arbutin, cellobiose, D-fructose, gentiobiose, $\alpha$-D-glucose, maltose, maltotriose, D-mannose, melibiose, D-psicose and salicin as sole carbon source. Cell wall contains meso-diaminopimelic acid and rhamnose. The predominant menaquinone is MK-7. The major cellular fatty acids are anteiso- $\mathrm{C}_{15: 0}$ and $\mathrm{C}_{16: 0}$. Diphosphatidylglycerol, phosphatidylethanolamine and two unknown phosphoglycolipids are the major polar lipids. The DNA G $+C$ content of the type strain is $47.0 \mathrm{~mol} \%$.

The type strain is $\mathrm{XJ} 259^{\mathrm{T}}\left(=\mathrm{CGMCC} 1.10223^{\mathrm{T}}=\mathrm{JCM}\right.$ $16598^{\mathrm{T}}$ ), isolated from a cold spring from Xinjiang Uyghur Autonomous Region in China.

\section{Acknowledgements}

This research work was kindly supported in part by grants from National Basic Research Program of China (no. 2010CB833800), High-Tech Research and Development Program of China (grant no. 2007AA021300), Chinese Ministry of Agriculture (no. 200803034), National Natural Science Foundation of China (no. 30700015), National 863 Project (nos. 2006AA09Z402 and 2007AA09Z443) and Chinese Academy of Sciences Innovation Project O62A131BB4.

\section{References}

Altschul, S. F., Madden, T. L., Schäffer, A. A., Zhang, J., Zhang, Z., Miller, W. \& Lipman, D. J. (1997). Gapped BLAST and PSI-BLAST: a new generation of protein database search programs. Nucleic Acids Res 25, 3389-3402.

Ash, C., Priest, F. G. \& Collins, M. D. (1993). Molecular identification of rRNA group 3 bacilli (Ash, Farrow, Wallbanks and Collins) using a PCR probe test. Proposal for the creation of a new genus Paenibacillus. Antonie van Leeuwenhoek 64, 253-260.

Ash, C., Priest, F. G. \& Collins, M. D. (1994). Paenibacillus gen nov. In Validation of the Publication of New Names and New Combinations
Previously Effectively Published Outside the IJSB, List no. 51. Int J Syst Bacteriol 44, 852.

Barrow, G. I. \& Feltham, R. K. A. (editors) (1993). Cowan and Steel's Manual for Identification of Medical Bacteria, 3rd edn. Cambridge: Cambridge University Press.

Berge, O., Guinebretière, M. H., Achouak, W., Normand, P. \& Heulin, T. (2002). Paenibacillus graminis sp. nov. and Paenibacillus odorifer sp. nov., isolated from plant roots, soil and food. Int J Syst Evol Microbiol 52, 607-616.

Chou, J.-H., Chou, Y.-J., Lin, K.-Y., Sheu, S.-Y., Sheu, D.-S., Arun, A.-B., Young, C.-C. \& Chen, W.-M. (2007). Paenibacillus fonticola sp. nov., isolated from a warm spring. Int J Syst Evol Microbiol 57, 1346-1350.

Chun, J., Lee, J.-H., Jung, Y., Kim, M., Kim, S., Kim, B. K. \& Lim, Y.-W. (2007). EzTaxon: a web-based tool for the identification of prokaryotes based on $16 \mathrm{~S}$ ribosomal RNA gene sequences. Int J Syst Evol Microbiol 57, 2259-2261.

Claus, D. \& Berkeley, R. C. W. (1986). Genus Bacillus Cohn 1872, $174^{\mathrm{AL}}$. In Bergey's Manual of Systematic Bacteriology, vol. 2, pp. 11051139. Edited by P. H. A. Sneath, N. S. Mair, M. E. Sharpe \& J. G. Holt. Baltimore: Williams \& Wilkins.

Collins, M. D., Goodfellow, M. \& Minnikin, D. E. (1980). Fatty acid, isoprenoid quinone and polar lipid composition in the classification of Curtobacterium and related taxa. J Gen Microbiol 118, 29-37.

Daane, L. L., Harjono, I., Barns, S. M., Launen, L. A., Palleron, N. J. \& Häggblom, M. M. (2002). PAH-degradation by Paenibacillus spp. and description of Paenibacillus naphthalenovorans sp. nov., a naphthalene-degrading bacterium from the rhizosphere of salt marsh plants. Int J Syst Evol Microbiol 52, 131-139.

Dasman, K., Kajiyama, S., Kawasaki, H., Yagi, M., Seki, T., Fukusaki, E. \& Kobayashi, A. (2002). Paenibacillus glycanilyticus sp. nov., a novel species that degrades heteropolysaccharide produced by the cyanobacterium Nostoc commune. Int J Syst Evol Microbiol 52, 1669-1674.

Felsenstein, J. (1981). Evolutionary trees from DNA sequences: a maximum likelihood approach. J Mol Evol 17, 368-376.

Felsenstein, J. (1985). Confidence limits on phylogenies: an approach using the bootstrap. Evolution 39, 783-791.

Felsenstein, J. (2002). PHYLIP (phylogenetic inference package), version 3.6a. Distributed by the author. Department of Genome Sciences, University of Washington, Seattle, USA.

Gomori, G. (1955). Preparation of buffers for use in enzyme studies. Methods Enzymol 1, 138-146.

Guindon, S., Lethiec, F., Duroux, P. \& Gascuel, O. (2005). PHYML online-a web server for fast maximum likelihood-based phylogenetic inference. Nucleic Acids Res 33 (Web Server issue), W557-W559.

Hucker, G. J. (1921). A new modification and application of the Gram stain. J Bacteriol 6, 395-397.

Jeon, C. O., Lim, J.-M., Lee, J.-M., Xu, L.-H., Jiang, C.-L. \& Kim, C.-J. (2005). Reclassification of Bacillus haloalkaliphilus Fritze 1996 as Alkalibacillus haloalkaliphilus gen. nov., comb. nov. and the description of Alkalibacillus salilacus sp. nov., a novel halophilic bacterium isolated from a salt lake in China. Int J Syst Evol Microbiol 55, 1891-1896.

Judicial Commission of the International Committee for Systematics of Prokaryotes (2005). The type species of the genus Paenibacillus Ash et al. 1994 is Paenibacillus polymyxa. Opinion 77. Int J Syst Evol Microbiol 55, 513.

Kates, M. (1986). Techniques of Lipidology, 2nd edn. Amsterdam: Elsevier.

Kim, B.-C., Jeong, W.-J., Kim, D. Y., Oh, H.-W., Kim, H., Park, D.-S., Park, H.-M. \& Bae, K. S. (2009). Paenibacillus pueri sp. nov., isolated from Pu'er tea. Int J Syst Evol Microbiol 59, 1002-1006. 
Kimura, M. (1980). A simple method for estimating evolutionary rates of base substitutions through comparative studies of nucleotide sequences. J Mol Evol 16, 111-120.

Kimura, M. (1983). The Neutral Theory of Molecular Evolution. Cambridge: Cambridge University Press.

Kluge, A. G. \& Farris, J. S. (1969). Quantitative phyletics and evolution of anurans. Syst Zool 18, 1-4.

Ko, K. S., Kim, Y.-S., Lee, M. Y., Shin, S. Y., Jung, D. S., Peck, K. R. \& Song, J.-H. (2008). Paenibacillus konsidensis sp. nov., isolated from a patient. Int J Syst Evol Microbiol 58, 2164-2168.

Komagata, K. \& Suzuki, K. (1987). Lipid and cell-wall analysis in bacterial systematics. Methods Microbiol 19, 161-207.

Kuisiene, N., Raugalas, J., Spröer, C., Kroppenstedt, R. M., Stuknyte, M. \& Chitavichius, D. (2008). Paenibacillus tylopili sp. nov., a chitinolytic bacterium isolated from the mycorhizosphere of Tylopilus felleus. Folia Microbiol (Praha) 53, 433-437.

Kumar, S., Nei, M., Dudley, J. \& Tamura, K. (2008). MEGA: a biologistcentric software for evolutionary analysis of DNA and protein sequences. Brief Bioinform 9, 299-306.

Lane, D. J. (1991). 16S/23S rRNA sequencing. In Nucleic Acid Techniques in Bacterial Systematics, pp. 115-175. Edited by E. Stackebrandt \& M. Goodfellow. Chichester: Wiley.

Leifson, E. (1963). Determination of carbohydrate metabolism of marine bacteria. J Bacteriol 85, 1183-1184.

Lim, J.-M., Jeon, C. O., Park, D.-J., Xu, L.-H., Jiang, C.-L. \& Kim, C.-J. (2006). Paenibacillus xinjiangensis sp. nov., isolated from Xinjiang province in China. Int J Syst Evol Microbiol 56, 2579-2582.

Mandel, M. \& Marmur, J. (1968). Use of ultraviolet absorbance temperature profile for determining the guanine plus cytosine content of DNA. Methods Enzymol 12B, 195-206.

Montes, M. J., Mercadé, E., Bozal, N. \& Guinea, J. (2004). Paenibacillus antarcticus sp. nov., a novel psychrotolerant organism from the Antarctic environment. Int J Syst Evol Microbiol 54, 15211526.

Park, D.-S., Jeong, W.-J., Lee, K. H., Oh, H.-W., Kim, B.-C., Bae, K. S. \& Park, H.-Y. (2009). Paenibacillus pectinilyticus sp. nov., isolated from the gut of Diestrammena apicalis. Int J Syst Evol Microbiol 59, 13421347.

Rivas, R., Mateos, P. F., Martínez-Molina, E. \& Velázquez, E. (2005). Paenibacillus phyllosphaerae sp. nov., a xylanolytic bacterium isolated from the phyllosphere of Phoenix dactylifera. Int J Syst Evol Microbiol 55, 743-746.

Rivas, R., Garcia-Fraile, P., Mateos, P. F., Martínez-Molina, E. \& Velázquez, E. (2006). Paenibacillus cellulosilyticus sp. nov., a cellulolytic and xylanolytic bacterium isolated from the bract phyllosphere of Phoenix dactylifera. Int J Syst Evol Microbiol 56, 2777-2781.
Roux, V. \& Raoult, D. (2004). Paenibacillus massiliensis sp. nov., Paenibacillus sanguinis sp. nov. and Paenibacillus timonensis sp. nov., isolated from blood cultures. Int J Syst Evol Microbiol 54, 1049-1054.

Roux, V., Fenner, L. \& Raoult, D. (2008). Paenibacillus provencensis sp. nov., isolated from human cerebrospinal fluid, and Paenibacillus urinalis sp. nov., isolated from human urine. Int J Syst Evol Microbiol 58, 682-687.

Saha, P., Mondal, A. K., Mayilraj, S., Krishnamurthi, S., Bhattacharya, A. \& Chakrabarti, T. (2005). Paenibacillus assamensis sp. nov., a novel bacterium isolated from a warm spring in Assam, India. Int J Syst Evol Microbiol 55, 2577-2581.

Saitou, N. \& Nei, M. (1987). The neighbor-joining method: a new method for reconstructing phylogenetic trees. Mol Biol Evol 4, 406425.

Schleifer, K. H. \& Kandler, O. (1972). Peptidoglycan types of bacterial cell walls and their taxonomic implications. Bacteriol Rev 36, 407-477.

Shida, O., Takagi, H., Kadowaki, K., Nakamura, L. K. \& Komagata, K. (1997). Transfer of Bacillus alginolyticus, Bacillus chondroitinus, Bacillus curdlanolyticus, Bacillus glucanolyticus, Bacillus kobensis, and Bacillus thiaminolyticus to the genus Paenibacillus and emended description of the genus Paenibacillus. Int J Syst Bacteriol 47, 289-298.

Smibert, R. M. \& Krieg, N. R. (1981). General characterization. In Manual of Methods for General Bacteriology, pp. 409-443. Edited by P. Gerhardt, R. G. E. Murray, R. N. Costilow, E. W. Nester, W. A. Wood, N. R. Krieg \& G. B. Phillips. Washington, DC: American Society for Microbiology.

Takeda, M., Suzuki, I. \& Koizumi, J. (2005). Paenibacillus hodogayensis sp. nov., capable of degrading the polysaccharide produced by Sphaerotilus natans. Int J Syst Evol Microbiol 55, 737-741.

Tamura, K., Dudley, J., Nei, M. \& Kumar, S. (2007). MEGA4: molecular evolutionary genetics analysis (MEGA) software version 4.0. Mol Biol Evol 24, 1596-1599.

Thompson, J. D., Gibson, T. J., Plewniak, F., Jeanmougin, F. \& Higgins, D. G. (1997). The CLUSTAL_X windows interface: flexible strategies for multiple sequence alignment aided by quality analysis tools. Nucleic Acids Res 25, 4876-4882.

Valverde, A., Peix, A., Rivas, R., Velázquez, E., Salazar, S., Santa-Regina, I., Rodriguez-Barrueco, C. \& Igual, J. M. (2008). Paenibacillus castaneae sp. nov., isolated from the phyllosphere of Castanea sativa Miller. Int J Syst Evol Microbiol 58, 2560-2564.

Velázquez, E., de Miguel, T., Poza, M., Rivas, R., Rosselló-Mora, R. \& Villa, T. G. (2004). Paenibacillus favisporus sp. nov., a xylanolytic bacterium isolated from cow faeces. Int J Syst Evol Microbiol 54, 59-64.

Yoon, J.-H., Kang, S.-J., Yeo, S.-H. \& Oh, T.-K. (2005). Paenibacillus alkaliterrae sp. nov., isolated from an alkaline soil in Korea. Int J Syst Evol Microbiol 55, 2339-2344. 